\title{
Inauguration of the Materials Research Society of Japan (MRS-Japan) - Influence of Two American Scholars - Professors R. P. H. (Bob) Chang and Rustum Roy
}

\author{
Shigeyuki Somiya \\ Professor Emeritus \\ Tokyo Institute of Technology \\ Teikyo University of Science and Technology \\ Present address: 3-7-19 Seijo, Setagaya, Tokyo 157-0066, Japan
}

Fax: $+81-3-3415-6619$

Professor R. P. H. (Bob) Chang (Picture 1) came to Japan in 1985 to establish MRS-Japan. Along with around 20 Japanese applied physicists, Professor Masao Doyama and I met Bob at that time. Bob was able to speak and understand Chinese, English, and Japanese and had a cooperative, international mindset. Although this was the first time for me to meet him, a number of Japanese applied physicists had prior dealings with Bob and had organized international meetings such as the International Conference on Electronic Materials (ICEM) and the International Conference on Ion Beam Modification of Materials (IBMM), both of which were cosponsored by the Japanese Society of Applied Physics and MRS.

Bob's father studied medicine in Japan, and his mother studied in Japan, too. They married during World War II and returned to mainland China. Bob was born in Chongquig (重慶), and his family moved to Shang-hai after the war. After spending three years in Shang-hai, Bob's parents decided to move to Hong Kong because his father was receiving increasing scrutiny from the Chinese Communist Party. He looked like a rich man, although there was no real evidence to prove that he really was.

Bob's father was not able to work as a medical doctor in Hong Kong because Hong Kong was a colony of Great Britain. As public safety grew increasingly worse in Hong Kong, Bob's parents wanted to move to Japan. In 1952, Bob's family came to Japan and eventually settled in Seijo, Tokyo.

A year after graduating from high school in Tokyo, Bob enrolled in a university in the United States and later transferred as a student to the Department of Physics at M.I.T., where he received his bachelor's degree in physics. He entered the Department of Astronomy at Princeton University as a graduate student to study astrophysics. After receiving his $\mathrm{Ph} . \mathrm{D}$. in astrophysics with an emphasis in plasma physics, he went to work for Bell Laboratories, and in 1986 joined Northwestern University as a faculty member.

Professor Masao Doyama from the University of Tokyo and I discussed Bob's proposal to establish MRS-Japan. Then we investigated to see how many Japanese scientists would attend such a meeting.
Professor Doyama is a well-known physical scientist. He graduated from the Department of Metallurgy at the University of Tokyo, and received his M.S. in metallurgy from the University of Notre Dame and his $\mathrm{Ph} . \mathrm{D}$. in physics from the University of Illinois, both in the United States. He worked at Argonne National Laboratory as a physicist and later returned to the University of Tokyo as a professor. He is well known throughout the world as a physicist.

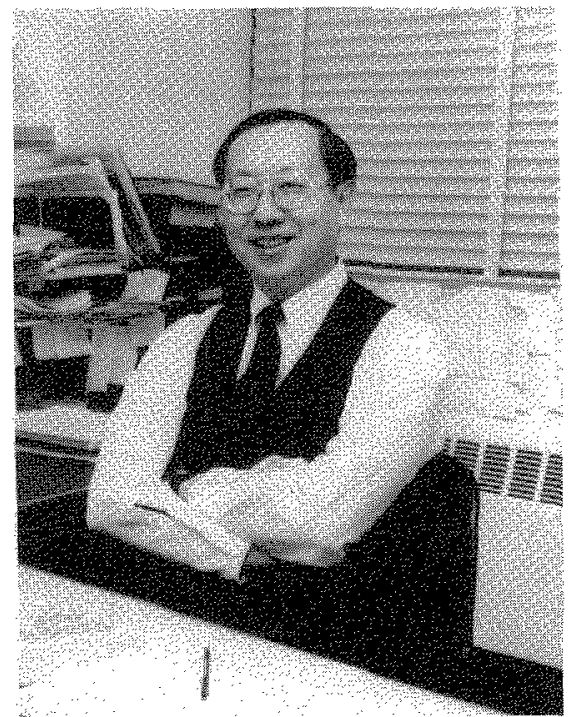

Picture 1. Professor Bob Chang (around 1991).

I graduated from Tokyo Institute of Technology and went to the United States. At that time, the Department of Geochemistry at the Pennsylvania State University was one of the leading universities in the world studying phase equilibria, mineral synthesis, and crystal chemistry. I was a graduate student in the Department of Geochemistry under the Fulbright exchange student program and was studying phase equilibrium among oxides in steel making under the guidance of Professors E. F. Osborn and A. Muan. After returning to Japan, I began to study hydrothermal processing. At that time, my laboratory had a number of Tuttle-Roy bombs. Our laboratory was one of five large hydrothermal laboratories throughout the world 
that had a great deal of equipment.

When Bob came to Japan, I was an editor and later became an associate editor of the Journal of Materials Research (JMR). I believe that I was selected as an editor for JMR based on the recommendation of Professor Rustum Roy.

Professor Doyama and I discussed Bob's proposal and decided to organize an international conference to see how many scientists would attend such a conference. The first MRS international conference was held at Sunshine City, Tokyo, Japan, from May 30 to June 3, 1988. Over 1,600 scientists and engineers gathered from 25 countries for 21 symposia. The conference was a success, and the proceedings of this conference were published by the MRS office a year later. The executive editors were Professors Doyama, Somiya, and Chang. The following excerpt is from the introduction to the proceedings:

As advanced technology continues to develop higher and higher, it is often constrained because suitable or satisfactory materials are not available. Developing materials with a special purpose is "needs-oriented research." For example, the efficiency of engines is higher for higher working temperature. Materials which tolerate higher temperature are sought. Ceramics engines are available if the micro-cracks on the surface can be controlled. There is also "seeds-oriented materials research." Many seeds can be found in the symposia from this meeting. The broad fields addressed during this MRS meeting cannot be covered adequately by traditional existing professional societies.

Another uniqueness of this meeting is that this meeting is solely sponsored by Nikkan Kogyo Shimbun, an industrial newspaper company.

We express sincere thanks to the chairs of the symposia, editors of the Proceedings and Nikkan Kogyo Shimbun for their devoted cooperation.

After the meeting, Professor Doyama, Dr. Kiyoshi Inoue of Japax Co. Ltd., Mr. Yoshitaka Agata of Kanagawa Science Park (KSP), and I met on March 16, 1989, in Tokyo, and discussed the establishment of the Advanced Materials Science and Engineering Society (AMSES).

The first President of AMSES, Professor Masao Doyama, gave the following address:

As advanced technology develops toward its highest goals, a small improvement in existing materials is not enough to meet the demands. The deadlock of advanced technology often brings the invention of new materials.

Human civilization has grown along with materials.
The Stone Age, the Bronze Age, and the Iron Age represent the materials most used in those times. Since the beginning of the $20^{\text {th }}$ century, the plastic age, the semiconductor age, the new ceramics age, and the composite materials age have been identified, but no single material dominates.

In addition to the traditional classification of materials (the warp) such as metals, semiconductors, ceramics and organic materials, materials have to be studied by the woof. After World War II, metallurgy hit a deadlock. To overcome the deadlock, metallurgy changed to materials science, absorbing the knowledge of physics, chemistry, chemical engineering, electrical engineering, mechanical engineering, civil engineering, etc., and collaborating with ceramics, semiconductors, and organic materials.

This movement was not successful in Japan because at that time the production of iron and steel in Japan was increasing very rapidly, and the country could not spare a sidelong glance at other fields. Now the iron and steel industry in Japan has reached maturity, and the value of materials science is being rediscovered in Japan. In organic materials, the properties of single molecules reflect those of the entire product. Synthesis is emphasized. Fracture can be treated by itself or in comparison among metals, semiconductors, ceramics and organic, rheology and amorphous materials. The complexity of the problem cannot be adequately addressed by traditional societies.

Process, properties, structure, and environment are the four elements of materials. Without good processes, good materials cannot be made. In the future, the development of materials must be made from a broad perspective and must be useful for mankind.

The first activity of MRS was as early as April, 1966 by Professor R. Roy and the first national meeting of Materials Research Society was held May 22-25, 1973 at the Pennsylvania State University. MRS has grown rapidly with the strategy of materials science and flexibility. The MRS International Conference on Advanced Materials held in Tokyo, Japan drew 1600 participants and proved a great success. The Advanced Materials Science and Engineering Society of Japan was established by the kind invitation of MRS President R. P. $\mathrm{H}$. Chang through the collaboration of Professor Somiya and Dr. K. Inoue. This Society is an international society holding a strong connection with MRS.

On the occasion of the founding of the Advanced Materials Science and Engineering Society, we respectfully request your guidance and warm support.

The International Materials Research Committee was established in September 1989 and AMSES was recognized as one of the founding society of this Committee world-wide and also as the only society in Japan in November 1989 . Since then, many societies related to materials have changed their names and used the abbreviation MRS. The Executive Editors 
therefore thought it preferable to change the name from AMSES to MRS-Japan, the Materials Research Society of Japan.

It was easier to say MRS-Japan than AMSES, especially in Japanese, and the name MRS was more widespread than AMSES. It was therefore decided to change the name before the publication of these transactions of the Materials Research Socicty of Japan.

International Union of Materials Research Societies was established in 1991 consisting eight Materials Research Societies from around the world such as MRS-J, MRS-Europe, MRS-Korea, MRS-China, and so on. The first president of IUMRS was Professor Bob Chang.

MRS-Japan had published the News Letters four times in a year since 1989 among the members and then it was changed to quarterly journals. Professor Doyama and I wanted more good communications among the members and friend-ship too. And also we wanted to promote the developments of science and technology of materials more and more. Professor Bob Chang made an address to our journal:

It is with honor and great pleasure that we thank Professor Masao Doyama and Professor Shige Somiya for their effort in launching a quarternary journal of the Transactions of the Materials Research Society of Japan. They were not only responsible for the birth of the Materials Research Society of Japan (MRS-J), but they have also nurtured it over the years. The success and maturity of MRS-J are indeed due to the efforts of all the members. On behalf of the International Union of Materials Research Societies, I send best regards to a successful new publication. We look forward to many articles in this new journal that will inspire all of us in the materials community.

\section{R. P. H. Chang}

Founding President,

International Union of Materials Research Societies May, 1989

Professor Rustum Roy, an American scholar, provided help and advice to Japanese scientists and the Materials Research Society of Japan. Professor Roy recommended Professor Doyama and I as staff members for MRS and/or MRS editor.

Professor R. Roy (Picture 2) was born July 3, 1924 in Ranchi, Bihar Province, India. He obtained his B.S. and M.S. in physical chemistry from Patna University and his Ph.D. in ceramics from Pennsylvania State University. He started to work at the Department of Chemistry as a research associate, and within one year, he joined the Department of Ceramics. He advanced from a research associate to become a full professor of geochemistry in 1957 . His research fields were very wide ranging.

i) Fundamental: (1) crystal chemistry, (2) crystal growth, (3) phase equilibrium studies in model systems, (4) dry and wet systems, and (5) high-temperature and high-pressure systems, including Ba-titanate systems.

ii) Discovery of new materials: (1) zero-expansion ceramics, (2) synthesis of garnets, including rare earth elements, (3) nano-composites, (4) synthesis of clay minerals, synthesis of mica, (5) diamond films, and (6) synthesis of semiconductors.

iii) Discovery of new processing: (1) sol-gel process, (2) hydrothermal process, (3) glass-ceramic process, (4) synthesis of fine particles: a) reaction electrode submerged arc process and $b$ ) high-temperature spray hydrolysis process, (5) application to sintering of ceramics, and (6) synthesis of materials by laser.

iv) Management: radioactive waste management

Many Japanese scientists received good advice from Professor Roy. In order to make it easier for his Japanese colleagues, he spoke slowly when speaking in English, and his sentences consisted almost entirely of English nouns without verbs or adjectives. Moreover, he introduced Japanese scientists to his friends as well as to appropriate American authorities. In one year, he even received more than 200 visitors from Japan.

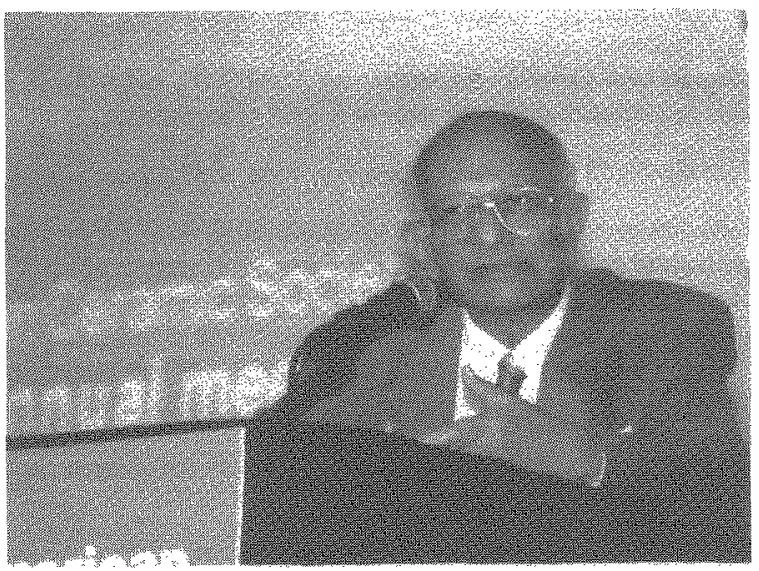

Picture 2. Professor Rustum Roy,

In 1993, Professor Roy attended the International Mecting on Advanced Materials in Tokyo. He was the first American organizer of the first U.S.-Japan Seminar on Basic Ceramics under the sponsorship of the U.S. National Science Foundation and the Japan Society for the Promotion of Science. The themes of the first (1969) and second (1972) meetings were "Characterization of Ceramic Materials" and "Equilibria and Kinetics in Modern Ceramics Process", respectively. Professor Roy was the American coordinator for both meetings.

Professor Roy has authored or coauthored more than 1,000 books and/or papers in fields ranging from materials science to religion. Professor Roy had knowledge on a wide range of subjects and was very friendly and open-minded. 
Professor Roy passed away in August, 2010. His last message was "Think positive, be persistent in your pursuit and you will attain success."

Acknowledgements

I would like to express my sincerely gratitude to all of the individuals who worked with me to establish the Materials Research Society of Japan.

\section{References}

1) About Professor R. P H. (Bob) Chang

(a) S. Somiya, Materials Integration, 21 [10] 60-67 (2008).

2) About Professor Rustum Roy

(a) K. L. Woodard, Profiles in ceramics, Rustum Roy, Am. Ceram. Soc. Bull., 79 [12] 36-42 $(2000)$.

(b) S. Somiya, Materials Integration, 17 [4] 87-93 (2004). 第 2 次世界大戦後の日本のセラミ ックス科学の発達に、友好や親善に尽力し た世界の大学教授(5) セラミックスの偉 才、異能の長老 アメリカ、ペンシルバニ ア州立大学教授、Rustum Roy 教授

(c) Peter Wray, Rustum Roy, 1924-2010, August 30, 2010, pp. 1-3.

(d) C. White, Renowned Penn State Geochemist Ray dies at age 86, August 27, 2010 http://www.centerdaily.com/2010/08/27/2173 274/renowed-Penn-State

3) About MRS

(a) MRS Bull., September, 73-88 (1993).

(Received September 12, 2011) 